\title{
Analisis Potensi Wilayah Dharmasraya Untuk Pengembangan Sapi Potong dan Kaitannya Dengan Pemberdayaan Ekonomi Masyarakat
}

\section{Potency Analysis Dharmasraya Farming for Developing Cattle Beef and Relationship with Society Economic Empowerment}

\author{
Ediset, dan E. Heriyanto
}

Fakultas Peternakan Universitas Andalas,

Kampus Unand Limau Manis Padang, 25163

email: edisetjami80@gmail.com

(Diterima: 25 Juni 2012 ; Disetujui: 29 September 2012)

\begin{abstract}
The research was goals : 1) To be able Dharmasraya potency for developing beef cattle farming. 2) To be able existing condition attempt cattle live stock and the relationship means empowerment society economy. Approach research was secondary data analysis and survey. Sample all of cattle live stock which breeding cattle live stock intensively, taking sample by cluster random sampling. Respondent was choose by simple random sampling, primary data was collected by interview directly and questioner and secondary data collect from relevant agency. Then both of data were analyzed qualitative and quantitative. Proceed of research showed Dharmasraya has potency for developing cattle live stock could view from : 1) Aspect of natural resources region such as land available. 2) Region social culture aspect such as number of breeder, education of breeder and tradition of breeding of live stock. 3) Board aspect such as monetary, government administration, information and technology. Existing condition breed of live stock that indicated to empowerment society economy which viewed based on marketing aspect and absorbing employee. Based on proceed of researched we could concluded that Dharmasraya had good potent for developing live stock, and breed existing condition for cattle live stock that indicated for empowerment society economy.
\end{abstract}

Keyword : potency, existing, condition, empowerment.

\section{PENDAHULUAN}

Kabupaten Dharmasraya terdiri dari empat Kecamatan yaitu Kecamatan Sungai Rumbai, Kecamatan Koto baru, Kecamatan Sitiung dan Kecamatan Pulau punjung, Kabupaten Dharmasraya memiliki populasi ternak sapi potong 12.666 ekor, dengan klasifikasi 3.219 jantan dan 9.447 betina (Dinas Pertanian dan Kehutanan Kabupaten Dharmasraya, 2006). Populasi ternak sapi potong yang terbanyak terdapat di Kecamatan Koto baru yaitu 5.229 ekor dan Kecamatan Sitiung 4.368 ekor, Kecamatan Pulau Punjung 1.465 ekor dan Kecamatan Sungai Rumbai 1.604 ekor.

Melihat kondisi ini, usaha pengembangan usaha ternak sapi potong masih perlu dilakukan karena selama ini pemenuhan kebutuhan daging sapi di wilayah ini sebagian besar didatangkan dari daerah lain terutama dari Provinsi Medan dan Provinsi Lampung. Kabupaten Dharmasraya sebagai suatu wilayah yang terletak di daerah Provinsi Sumatera Barat dalam hal ini mempunyai peluang untuk mengembangkan usaha ternak sapi karena secara umum Kabupaten Dharmasraya mempunyai kelebihan yang dapat mendukung upaya pengembangan lebih lanjut, seperti tersedianya sumber daya alam maupun sumber daya manusia. Daya dukung lain yang dimiliki Kabupaten Dharmasraya adalah fasilitas penunjang, petugas IB, Dinas Keswan, distributor pakan dan obat-obatan serta letak wilayah yang sangat strategis karena Kabupaten 
ini berbatasan langsung dengan Provinsi tetangga sebagai wilayah pemasaran, yaitu Provinsi Riau dan Provinsi Jambi.

Ketersediaan sumberdaya untuk pengembangan peternakan semakin lama dapat dirasakan semakin berkurang, hal ini diikuti dengan persaingan antar sub sektor yang lain, seperti sub sektor tanaman pangan, perkebunan dan sektor lain seperti lokasi pemukiman, perindustrian dan kebutuhan akan sumberdaya lainnya. Sehubungan dengan itu perlu pengalokasian dan penggunaan sumber daya yang tepat dan efektif untuk optimalisasi produksi dalam pengembangan usaha peternakan sehingga perlu dipersiapkan lokasi yang berpotensi sebagai wilayah pengembangan peternakan.

Kabupaten Dharmasraya sebagai alternatif untuk pengembangan usaha ternak sapi didasarkan pada beberapa alasan penting seperti sumber daya alam dan sumber daya manusia yang dimiliki Kabupaten Dharmasraya, keadaan lingkungan yang baik, tersedianya sarana dan prasarana yang memadai serta fasilitas pendukung. Walaupun demikian, perlu terlihat suatu wilayah khusus pengembangan ternak sapi yang terkoordinasi dengan baik. Untuk itu perlu dilakukan suatu kajian tentang potensi masing-masing wilayah (kecamatan) yang ada di Kabupaten Dharmasraya, sehingga dapat diketahui wilayah yang berpotensi untuk pengembangan peternakan sapi potong dengan melihat sumber daya yang dimiliki oleh wilayah tersebut dimana sumberdaya akan dilihat dari berbagai segi baik jumlah, jenis maupun kualitas. Setelah dikaji maka untuk pengembangan dapat disusun suatu rencana strategi pengembangan yang sesuai untuk dilakukan pada wilayah tersebut dengan memperhatikan faktor internal dan faktor eksternal wilayah.

\section{METODE}

\section{Tempat dan Waktu Penelitian}

Penelitian dilakukan pada wilayah Kabupaten Dharmasraya. Pengambilan sampel terhadap data primer dilakukan pada satu Kecamatan, yaitu Kecamatan Koto Baru berdasarkan kriteria jumlah populasi ternak sapi potong terbanyak dan akses yang mudah ke lokasi penelitian.

\section{Pendekatan Penelitian}

Pada penelitian ini akan digunakan dua pendekatan, yaitu pendekatan analisa data sekunder dan pendekatan survey. Pendekatan Analisa Data Sekunder, digunakan untuk mengetahui potensi Kabupaten Dharmasraya.

Pendekatan survey, untuk mengetahui keterkaitan kondisi eksisting usaha pemeliharaan sapi potong dengan upaya pemberdayaan ekonomi masyarakat.

\section{Populasi dan Sampel}

Populasi dalam penelitian ini adalah seluruh Rumah Tangga Peternak (RTP) di Kecamatan Koto Baru berdasarkan populasi terbanyak.

Dari populasi 1.957 RTP akan diambil sampel sebanyak 95, untuk pengambilan besarnya sampel ditentukan dengan formula Slovin (Agustar, 1996) sebagai berikut :

$$
\begin{gathered}
\mathrm{n}=\frac{\mathrm{N}}{1+\mathrm{Ne}^{2}} \\
\mathrm{n}=\frac{1.957}{1+(1.957)(0,1)^{2}}=\frac{1.957}{1+19,57}=\frac{1.957}{20,57} \mathrm{n}=95
\end{gathered}
$$

Dimana :

$\mathrm{n}=$ Jumlah sampel

$\mathrm{N}=$ Jumlah populasi keseluruhan peternak sapi potong

$\mathrm{E}=$ Batas ketelitian yang diinginkan $(10 \%)$

Setiap Kanagarian diambil sampel secara proposional yaitu dengan rumus sebagai berikut:

$$
\mathrm{ni}=\frac{\mathrm{Ni}}{\mathrm{N}} x \mathrm{n}
$$

Dimana :

ni = Jumlah sampel Kenagarian

$\mathrm{Ni}=$ Populasi Kenagarian

$\mathrm{N}=$ Total populasi keseluruhan

Metode pengambilan sampel dilakukan dengan cluster random sampling yang akan dijadikan cluster adalah wilayah administratif dalam kabupaten. Kabupaten Dharmasraya 
terdiri dari empat Kecamatan oleh sebab itu pada populasi ditetapkan empat cluster. Selanjutnya populasi dan sampel dapat dilihat pada Tabel 1 .

Tabel 1. Populasi dan Sampel

\begin{tabular}{lcc}
\hline Kenagarian & Populasi RTP (Ni) & Sampel RTP (ni) \\
\hline Sialang gaung & 425 & 21 \\
Padang lawas & 205 & 10 \\
Sei. Langkok & 456 & 22 \\
Koto salak & 871 & 42 \\
\hline \multicolumn{1}{c}{ Jumlah } & 1.957 & 95 \\
\hline
\end{tabular}

\section{Informan Kunci}

Selain dari responden, pada penelitian ini data primer juga diperoleh dari informan kunci. Informan kunci itu adalah sebagai berikut :

1. KCD Peternakan (1 orang)

2. Kepala UPTD masing-masing Kecamatan (4 orang)

3. Penyuluh Pertanian Lapangan (6 orang)

4. Pedagang Peternak ( 3 )

\section{Metoda Pengumpulan Data}

Penelitian ini menggunakan metode survei. sumber data primer dikumpulkan melalui wawancara langsung dengan petani peternak yang menjadi sampel dengan menggunakan daftar pertanyaan yang terpola dan terstruktur sesuai dengan kebutuhan akan data yang mengacu pada topik dan tujuan penelitian,

Sumber data sekunder didapat dari instansi terkait. Disamping menggunakan daftar pertanyaan atau Questionair, juga melalui media diskusi yang akan melibatkan sebanyak mungkin stakeholder terutama petani peternak, kelompok peternak, pengusaha ternak, pihak perbankan, dan Dinas Peternakan.

\section{Analisis Data}

Analisis deskriptif dalam penelitian ini digunakan untuk mengetahui potensi usaha peternakan sapi potong dilakukan analisa SWOT. Analisis SWOT akan sangat berguna bagi strategi dalam perencanaan dan pengem- bangan peternakan. Rangkuti (2000) Beberapa faktor penting yang akan dianalisis adalah faktor internal yang terdiri dari: 1). Kekuatan (Strength, dan 2). Kelemahan/Weakneass, serta faktor Eksternal yang terdiri dari: 1). Peluang /Opportunities, dan 2. Ancaman ITreathness.

Metode Kapasitas Penambahan Populasi Ternak Ruminasia (KPPTR). Metode ini merujuk pada metode Nell dan Rollinson (1974).

Total produksi HMT dirumuskan sebagai berikut:

\section{3,75 x total luas lahan + total luas panen $\mathrm{x}$ koefisien prod. HMT}

Daya Tampung Wilayah dirumuskan sebagai berikut:

Total Produksi HMT/ 2,3

Nilai KPPTR dirumuskan sebagai :

Daya Tampung Wilayah-Populasi riel ternak

Dimana :

Kebutuhan Berat Kering untuk Satu Satuan Ternak adalah 2,3 ton/tahun

\section{HASIL DAN PEMBAHASAN}

Potensi Kabupaten Dharmasraya untuk pengembangan sapi potong terdiri dari potensi sumber daya alam Kabupaten Dharmasraya diantaranya ketersediaan lahan dan ketersediaan pakan.

\section{Kondisi Eksisting Pemeliharaan Sapi Potong dan Kaitannya dengan Pemberda- yaan Ekonomi Masyarakat}

Kondisi eksisting pemeliharaan sapi potong dan kaitannya dengan pemberdayaan ekonomi masyarakat terdiri dari kondisi sosial budaya, dukungan kelembagaan, pemeliharaan sapi potong dan pemberdayaan ekonomi serta usaha ternak sapi berindikasi terhadap pemberdayaan ekonomi masyarakat.

Kondisi sosial budaya yaitu jumlah pemeliharaan ternak, pendidikan peternak dan 
kebiasaan dalam pemeliharaan ternak. Sedangkan dukungan kelembagaan yaitu lembaga keuangan, administrasi pemerintahan dan informasi dan teknologi. Pemeliharaan sapi potong dan pemberdayaan ekonomi mencakup pemasaran, pembiayaan dan penyerapan tenaga kerja.

Jumlah Rumah Tangga Peternak (RTP) sapi potong di Kabupaten Dharmasraya pada tahun 2006 adalah sebanyak 5.409 RTP. Sebaran RTP ini dapat dilihat pada Tabel 6.

Pengaruh sarana dan prasarana pendidikan serta tingkat kesejahteraan tenaga pendidik tidak mempunyai pengaruh terhadap tingkat sumberdaya manusia pada sub sektor peternakan, di Kabupaten Dharmasraya. Untuk sub sektor peternakan tingkat sumberdaya yang ada tersebut sudah cukup memadai karena peternak yang memelihara ternak di daerah ini rata-rata berumur 46,5 tahun dan memiliki tingkat pendidikan yang cukup tinggi, dimana pendidikan peternak rata-rata 7,8 tahun.

Hal ini mengindikasikan bahwa peternak yang ada di wilayah ini semuanya sudah menamatkan pendidikan Sekolah Dasar (SD) dan peternak pada umumnya tidak belajar secara khusus untuk beternak namun mereka banyak belajar dari pengalaman yang mereka miliki. Hal ini dapat dilihat dari tingkat pengalaman peternak dalam beternak yang lebih dari 11 tahun, pengalamanan beternak yang cukup lama ini menggambarkan bahwa peternak di daerah ini sudah paham betul praktek dalam melakukan usaha ternak sapi potong itu sendiri, dan kondisi ini menjadi poin tersediri dalam upaya pengembangan usaha peternakan sapi potong lebih lanjut.

Usaha peternakan membutuhkan sumber daya yang terampil untuk pengembangannya, karena dalam melakukan usaha peternakan petani peternak mempunyai peranan ganda, dimana mulai dari usaha pemeliharaan ternak sampai dengan memasarkan hasil ternak dilakukan oleh peternak itu sendiri. Menurut Mosher (1991) dalam menjalankan usahanya tiap petani memegang peranan, petani adalah seorang jurutani (cultivator) dan sekaligus sebagai pengelolah (manager).
Usaha ternak sapi potong di Kabupaten Dharmasraya pada umumnya dilakukan sebagai usaha sambilan dan berfungsi sebagai tabungan karena pekerjaan utama dari peternak itu sendiri adalah sebagai petani. Peternak yang menjadikan usaha ternak sapi potong sebagai usaha pokok hanya $12,2 \%$. Meskipun begitu, pada dasarnya peternak di daerah ini sudah menjalankan usaha ternak sapi potong dalam kurun waktu yang cukup lama. Hal ini dapat dilihat dari tingkat pengalaman peternak dalam beternak yang lebih dari 11 tahun, dimana $88,4 \%$ peternak di daerah ini memiliki jumlah ternak sapi potong 1-4 ekor dengan komposisi ternak, dimana untuk induk seratus persen peternak rata rata memiliki induk ternak sapi potong, sedangkan yang memiliki pejantan hanya $29,4 \%$ peternak, kekurangan penjantan bisa di antisipasi dengan keberadaan teknologi IB yang sudah sering digunakan peternak dalam usaha budidaya. Peternak yang memiliki sapi dara $29,4 \%$, jantan muda hanya dimiliki oleh 14,7\% peternak saja, namun untuk anak sapi potong cukup menjanjikan karena sebanyak 29,5\% peternak memiliki anak jantan dan 34,7 \% peternak di daerah ini memiliki anak sapi potong betina dan bakalan ini bisa dipersiapkan untuk calon induk dan calon penjatan. Sistim pemeliharaan ternak yang cukup intensif, dimana lebih dari 56,8\% peternak mengkandangkan ternaknya siang dan malam secara terus menerus dan diberi pakan yang banyak, kemudian 37,9\% peterternak menambatkan ternaknya di ladang dan malam hari dikandangkan, sedangkan peternak yang melakukan sistim pemeliharaan ternak dengan melepaskan ternak di padang pengembalaan sepanjang hari dan malam hari dimasukan kekandang hanya $5,3 \%$. Sugeng (1992) menyatakan dalam rangka pemeliharaan secara intensif sapi-sapi memperoleh perlakuan yang lebih teratur atau rutin memberi pakan, pembersihan kandang, memandikan sapi, menimbang, mengendalikan penyakit dan sebagainya.

Pakan utama ternak sapi potong adalah a). Hijauan, seperti rumput, legum dan tumbuhan lain b). Limbah pertanian, seperti jerami, ampas tebu dan ampas tahu, c). pakan penguat 
(konsentrat), yaitu jagung giling, menir, dedak, katul, bungkil kelapa dan berbagai umbi, dan d). Pakan tambahan seperti vitamin, mineral dan urea (meningkatkan mutu jerami). Menurut Sugeng (1992) bahan pakan berupa hiajauan diberikan sebanyak $10 \%$ dari berat badan dan pakan penguat $1 \%$ dari berat badan sapi tersebut.

Rumput merupakan makanan utama ternak sapi dan biasanya pemberian itu di dukung oleh keberadaan dari rumput itu sendiri, begitu juga dengan tumbuhan lainnya, $20 \%$ peternak di daerah ini juga memberikan tumbuhan lain sebagai pakan ternak mereka, sedangkan pakan yang berjenis legume hanya $6,3 \%$ peternak yang memberikan sebagai makanan ternaknya. Begitu juga dengan jenis pakan yang berasal dari limbah pertanian hanya $0,1 \%$ peternak memberikan ampas tebu dan $11,6 \%$ peternak yang memberikan ampas tahu, sedangkan jerami sebagai limbah pertanian dari tanaman padi diberikan pada ternak sapi potong oleh $21,1 \%$ peternak sebagai pakan ternak mereka.

Pakan penguat (konsentrat), $77 \%$ peternak memberikan dedak sebagai pakan penguat, berbagai umbian juga diberikan oleh $20 \%$ peternak sebagai pakan penguat, sedangkan bungkil kelapa hanya 7,4\% peternak yang memberikannya sebagai penguat, jagung giling $0,1 \%$ peternak, bungkil kelapa $12,6 \%$ peternak. Mineral adalah pakan tambahan yang paling banyak diberikan oleh peternak terhadap ternak mereka, yaitu $42,1 \%$, sedangkan vitamin sebagai pakan tambahan hanya $15,8 \%$ peternak yang memberikannya, yang paling sedikit pakan tambahan yang diberikan adalah urea, dimana hanya $3,2 \%$ peternak yang memakai urea sebagai pakan tambahan. Obat-obatan yang biasanya untuk daerah ini masih sangat jarang digunakan, namun bila ternak terserang penyakit peternak mengobatinya dengan obat yang dibeli berdasarkan anjuran PPL, petugas IB dan dokter hewan yang ada.

Sementara peternak yang ada di daerah ini sangat sedikit menggunakan ternak mereka untuk fungsi lain, seperti ternak dipekerjakan dan biasanya peternak yang memelihara ternak sapi di daerah ini bertujuan untuk produksi daging, hal ini dapat dilihat hanya $3,2 \%$ peternak yang mempekerjakan ternak mereka, sedangkan $96,8 \%$ peternak tidak mempekerjakan sama sekali ternak mereka untuk pengolahan usaha tani lainnya.

Adapun lembaga keuangan sebagai pendukung kegiatan peternakan yang ada di Kabupaten Dharmasraya adalah : perbankan, Bank Mandiri, Bank BNI, Bank BRI, Bank BPD/Bank Kenagarian dan Bank Perkreditan Rakyat (BPR). Jumlah nasabah perbankan mencapai 24.360 nasabah, $98,48 \%$ merupakan nasabah tabungan, sisanya dalam bentuk giro dan deposito. Koperasi sebagai lembaga keuangan di daerah ini juga mengalami peningkatan unit, dimana pada tahun 2004 terdapat 115 unit koperasi dari jumlah ini diantaranya 45 unit berupa KUD, sedangkan non KUD sebanyak 71 unit (RPJM Kabupaten Dharmasraya, 2005-2010).

Administrasi pemerintahan, diantaranya Dinas Pertanian dan Kehutanan, Kepala Cabang Dinas Peternakan (KCD), Poskeswan, unit lapangan IB. Dari pihak swasta juga terdapat dukungan distributor pakan ternak, distributor obat-obatan hewan. Adapun jumlah inseminator pada unit lapangan IB berjumlah 16 inseminator untuk Kabupaten Dharmasraya, sedangkan jumlah tenaga Penyuluh Pertanian Lapangan (PPL) berjumlah sebanyak 52 orang (Dinas Pertanian dan Kehutanan Kabupaten Dharmasraya, 2006).

Media informasi yang sangat berperan di Kabupaten ini adalah tenaga penyuluh yang selalu mendamping petani (peternak), tenaga penyuluh sebagai fasilitator mengkonversikan informasi melalui kontak tani. Selanjutnya peternak di daerah ini juga dapat memperoleh informasi dari sesama peternak dan pedagang perantara yang ada.

Teknologi budidaya ternak sapi yang digunakan adalah teknologi IB dengan dukungan keberadaan inseminator yang tersebar di seluruh Kabupaten Dharmasraya. Namun demikian, keberadaan tenaga IB yang cukup memadai di daerah ini relatif kurang didukung oleh pengetahuan para peternak, seperti waktu mengawinkan ternak yang mana ternak sudah waktunya dikawinkan dan kebanyakan peternak itu sendiri tidak mengetahui akan hal itu. 
Kondisi yang seperti ini menggambarkan bahwa masih rendahnya pengetahuan peternak akan teknologi yang diterapkan. Soeprapto dan Abidin (2006) menyatakan bahwa pemilihan teknologi juga harus didasarkan pada kemampuan para peternak. Penggunaan teknologi yang terlaju maju justru menyebabkan para peternak mengalami kesulitan karena culture shock. Penggunaan teknologi secara tepat guna lebih mungkin diterapkan secara bertahap, misalnya penerapan seleksi bibit pada sapi lokal, kontrol perkawinan, serta pengelolaan dan penggunaan bahan pakan murah berkualitas.

Fasilitas penunjang bukan milik pemerintah seperti perusahaan pakan ternak, perusahaan obat hewan menjadi sangat penting keberadaannya dalam upaya pengembangan usaha ternak sapi potong, karena itu sebuah daerah harus dilengkapi dengan sarana produksi yang seperti ini.

Suatu dilema bila usaha pengembangan ternak sapi potong tidak di tunjang oleh keberadaan sarana produksi ini, untuk daerah Kabupaten Dharmasraya keberadaan sarana produksi ini sangat minim keberadaannya, yang paling lengkap keberadaanya hanya terdapat di Kecamatan Sitiung, yaitu terdapat dua unit distributor pakan dan obat-obatan ternak sedangkan di Kecamatan yang lain masih sangat minim keberadaanya berarti hal ini akan menjadi masalah bagi peternak yang berada daerah yang jauh keberadaannya dengan tempat beradanya sarana produksi tersebut dan kondisi ini juga diikuti oleh keengganan peternak itu sendiri dalam mencukupi segala kebutuhan ternaknya seperti obat-obatan, pakan tambahan dimana biasanya peternak di daerah ini seperti dalam hal pengobatan, peternak akan melakukan setelah mendapat anjuran dari tenaga kesehatan ternak yang ada kemudian baru mereka lakukan, dan para peternak jarang menyimpan obat-obatan atau pakan tambahan cadangan.

Aspek pemasaran itu adalah berupa tempat penjualan produk peternakan, umur ternak waktu penjualan, keberadaan pembeli pada saat ternak mau dijual, sistem penetapan harga dan sistem pembayaran dari pembeli kepada peternak.

Peternak pada umumnya melakukan penjualan ternak kepada pedagang peternak yang ada disekitar tempat tingal maupun yang datang dari daerah lain. Meskipun demikian, ada juga peternak yang memasarkan ternak mereka ke pasar ternak, kesesama peternak dan pegusaha peternakan namun hanya sebagian kecil peternak yang melakukannya yaitu sebesar $6,3 \%$ peternak saja.

Berdasarkan sumber modal, usaha peternakan sapi potong yang dilakukan di daerah ini merupakan usaha pribadi karena sebesar 93\% sumber modal usaha ternak sapi potong berasal dari dana pribadi/simpanan peternak. Ini menggambarkan bahwa bantuan dari pemerintah masih kecil, begitu juga dengan pinjaman modal dari lembaga keuangan baik dari pihak swasta (Lembaga Perbankan) maupun dari koperasi.

Pihak pemerintah yang diharapkan jadi inti dari pemberi bantuan modal terhadap peternak masih cukup sedikit realisasinya, dimana baru $9,5 \%$ peternak yang sudah menerima bantuan modal dari pemerintah. Sebaliknya $90,5 \%$ peternak didaerah ini belum pernah menerima bantuan modal dari pihak pemerintahan.

Sejalan dengan itu pinjaman baik yang berasal dari lembaga perbankan, pemerintahan maupun dari koperasi yang ada di wilayah ini juga masih cukup kecil. Kontribusi dari ketiga lembaga ini dalam memberikan pinjaman terhadap peternak sapi potong hanya baru mencapai $6,3 \%$ saja.

Akses terhadap peminjaman modal, baik pada pihak pemerintahan maupun pada pihak swasta (lembaga perbankan) masih cukup sulit. Dimana sebanyak $88,3 \%$ peternak di daerah ini mengatak kesulitan dalam mengakses pinjaman modal tersebut.

Upaya pengembangan usaha ternak sapi potong secara umum mengalami kesulitan permodalan di daerah ini, dimana $84,2 \%$ peternak yang ada di wilayah ini mengatakan kesulitan dalam hal permodalan usaha ternak sapi potong tersebut.

Peternak sapi potong di daerah ini ratarata memilki jumlah populsi yang masih 
sedikit, dimana sebanyak $88,4 \%$ peternak hanya memilki jumlah populasi berkisar dari 1-4 ekor. Biasanya dalam melakukan pemeliharaan melibatkan seluruh anggota keluarga untuk semua jenis pekerjaan dalam usaha pemeliharaan sapi potong. Keterlibatan anggota keluarga juga berbeda-beda dimana $34,7 \%$ yang terlibat itu adalah bapak atau ibu, $45,3 \%$ yang terlibat dalam usaha pemeliharaan adalah bapak atau ibu dan anak kemudian $18,9 \%$ yang terlibat adalah semua anggota keluarga dan hanya $1,1 \%$ yang melibatkan cucu mereka dalam usaha pemeliharaan ternak sapi potong.

\section{Analisa SWOT Pengembangan Sapi Potong Di Kabupaten Dharmasraya}

Hasil analisa faktor internal Kabupaten Dharmasraya menunjukan hasil positif. Hal ini berarti bahwa secara umum Kabupaten Dharmasraya masih mempunyai kekuatan untuk pengembangan ternak sapi potong, dimana kekuatan itu yang paling besar ada pada ketersediaan lahan dan ketersediaan pakan. Adapun kelemahan terbesar terdapat pada faktor pembiayaan usaha dan sumber daya manusia.

Hasil analisis faktor eksternal untuk Kabupaten Dharmasraya untuk pengembangan usaha ternak sapi potong secara umum menunjukan nilai yang cukup baik dengan skors positif. Peluang terbesar terdapat pada nilai RTP, dimana RTP yang ada di daerah ini masih rendah persentasenya apabila dilihat dari jumlah keseluruhan KK yang ada. Peluang selanjutnya terletak di peningkatan konsumsi yang berimplikasi pada peningkatan permintaan terhadap produk peternakan khususnya komoditi daging sapi. Walaupun demikian Kabupaten Dharmasraya juga menghadapi ancaman besar terutama pada daya tarik sektor lain dan kepadatan penduduk.

Keadaan ini memberikan gambaran umum wilayah Kabupaten Dharmasraya yang ternyata masih memiliki kekuatan internal, diantaranya kekuatan itu yang paling besar ada pada ketersediaan lahan dan pemasaran ternak dan juga masih memiliki peluang eksternal, seperti peluang terbesar terdapat pada nilai RTP, dimana RTP yang ada di daerah ini masih rendah persentasenya apabila dilihat dari jumlah keseluruhan KK yang ada. Peluang selanjutnya terletak di peningkatan konsumsi. Strategi pengembangan yang tepat untuk diterapkan untuk Kabupaten Dharmasraya dalam upaya pengembangan usaha ternak sapi potong adalah strategi agresif.

\section{KESIMPULAN}

Dari hasil dan pembahasan yang telah dilakukan pada bagian terdahulu dapat dikemukakan kesimpulan sebagai berikut :

1. Sumberdaya alam yang ada di Kabupaten Dharmasraya mempunyai potensi yang cukup besar di mana ketersediaan luas lahan garapan dan luas lahan panen cukup memadai untuk menghasilkan HMT sebagai pakan ternak ruminansia. Ketersediaan lahan ini juga sangat mendukung sebagai lahan penggembalan.

2. Ketersediaan pakan yang berasal dari kontribusi lahan garapan dan lahan luas panen dalam menghasilkan HMT masih cukup tinggi, secara keseluruhan ketersedian HMT Kabupaten Dharmasraya masih memiliki kelebihan, yang masih bisa menampung 3.194 ST lagi.

4. Kondisi iklim di daerah ini juga sangat mendukung untuk melakukan usahaternak sapi potong seperti suhu rata-rata bulanan dan Kelembaban.

5. Berdasarkan KPPTR yang dimiliki, maka Kecamatan Pulau Punjung dan Kecamatan Sungai Rumbai memiliki nilai KPPTR yang cukup besar, sehingga kedua Kecamatan tersebut merupakan Kecamatan yang potensial untuk pengembangan ternak sapi potong.

6. Kabupaten Dharmasraya memberi peluang untuk bertambahnya jumlah Rumah Tangga Peternak (RTP) yang pada gilirannya sektor peternakan akan semakin berkembang.

7. Kebiasaan dalam pemeliharaan ternak, peternak di daerah Kabupaten Dharmasraya ini menjadikan usaha ternak sapi potong sebagai usaha sambilan sedangkan usaha pokok mereka adalah sebagai petani 
biasa. Jumlah ternak yang masih skala kecil yaitu 1-4 ekor sapi potong dan pada dasarnya yang paling banyak dipelihara berdasarkan kelompok ternak adalah induk sapi potong. hanya sebahagian peternak yang mengkandangkan ternak sapi potong siang dan malam dan diberi pakan yang banyak, pakan yang diberikan, untuk hijauan yang banyak diberikan adalah rumput sedangkan limbah pertanian yang paling banyak diberikan adalah jerami dan peternak memberikan dedak sebagai pakan penguat ternak mereka sedangkan mineral adalah pakan tambahan yang diberikan oleh sebagian kecil peternak dan ternak sapi potong tidak dipergunakan untuk fungsi lain seperti ternak dipekerjakan berarti ternak sapi potong di daerah ini memang untuk menghasilkan produksi daging.

8. Fasilitas pendukung yang ada adalah lembaga keuangan berupa lembaga perbankan dan koperasi. Administrasi pemerintah yang menunjang usaha ternak sapi potong adalah seperti KCD, UPTD, Poskeswan, unit lapangan IB, inseminator dan PPL. Kemudian di dukung oleh informasi melalui fasilitator PPL dan kontak tani yang cukup memadai. Teknologi yang digunakan dalam usaha ternak sapi potong dalam upaya budidaya adalah teknologi IB.

9. Usaha ternak sapi potong di Kabupaten Dharmasraya memberikan indikasi terhadap pemberdayaan ekonomi masyarakat secara umum dan peternak khususnya berdasarkan akses pemasaran, akses pembiayaan dan penyerapan tenaga kerja.

10. Hasil analisa SWOT menunjukkan Kabupaten Dharmasraya masih mempunyai skors yang baik untuk dilakukan usaha pengembangan ternak sapi potong.

\section{DAFTAR PUSTAKA}

Agustar, A. 1999. Paradigma Baru Pembangunan Peternakan dan Kendala Penerapan Kebijaksanaan Pemerintah. Makalah Pada Seminar Pembangunan Peternakan Sumatera Barat Di POLITANI. Universitas Andalas .

Dinas Pertanian dan Kehutanan Kabupaten Dharmasraya. Laporan populasi Ternak dan Populasi Setelah Vaksinasi. 2006.

Draf Final RPJM. 2005. BAPEDA Kabupaten Dharmasraya.

Mosher, A.T. 1991. Menciptakan Struktur Pedesaan Yang Progresif. Jakarta: Yasaguna.

Nell,A.J. and D.H.L. Rollinson, 1974. The Requirement and Availability of Livestock Feed in Indonesia. UNDP/FAO/Ins/72/09/Jakarta.

Rangkuti, F. 2000. Analisa SWOT. Teknik Membedah Kasus Bisnis. Penerbit PT Gramedia Pustaka Utama. Jakarta.

Sugeng, B. Y. 1992. Pemeliharaan, Perbaikan Produksi, Prospek Bisnis dan Analisis Penggemukan Sapi Potong. Penebar Swadaya. Jakarta. 